This is the peer-reviewed version of the following article:

Stanic-Vucinic, D.; Nikolic, S.; Vlajic, K.; Radomirovic, M.; Mihailovic, J.; Cirkovic Velickovic, T.; Grguric-Sipka, S. The Interactions of the Ruthenium(II)-Cymene Complexes with Lysozyme and Cytochrome c. Journal of Biological Inorganic Chemistry 2020. https://doi.org/10.1007/s00775-020-01758-3

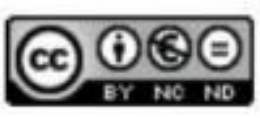

This work is licensed under a Creative Commons - Attribution-Noncommercial-No Derivative Works 3.0 Serbia 


\section{The interactions of the ruthenium(II)-cymene complexes with lysozyme and cytochrome c}

Short title: Interactions of the ruthenium(II)-cymene complexes with proteins

$$
\begin{aligned}
& \text { Dragana Stanic-Vucinic }{ }^{\mathrm{a}} \text {, Stefan Nikolic }{ }^{\mathrm{b}} \text {, Katarina Vlajic }{ }^{\mathrm{a}} \text {, Mirjana Radomirovic }{ }^{\mathrm{a}} \text {, Jelena } \\
& \text { Mihailovic }^{\mathrm{a}} \text {,Tanja Cirkovic Velickovic }{ }^{\mathrm{a}, \mathrm{c}, \mathrm{d}, \mathrm{e}}, \text { Sanja Grguric-Sipka } \\
& \text { f }
\end{aligned}
$$

aUniversity of Belgrade - Faculty of Chemistry, Center of Excellence for Molecular Food Sciences and Department of Biochemistry, Studentski trg 12-16, 11000 Belgrade, Serbia

${ }^{b}$ Innovation Center of the Faculty of Chemistry, University of Belgrade, Studentski trg 12-16, 11 000 Belgrade, Serbia

${ }^{\mathrm{c}}$ Ghent University Global Campus, 119 Songdomunhwa-Ro, Yeonsu-Gu, Incheon, Postal code: 21985, Korea

${ }^{\mathrm{d}}$ Faculty of Bioscience Engineering, Ghent University, Coupure Links 653, 9000 Ghent, Belgium

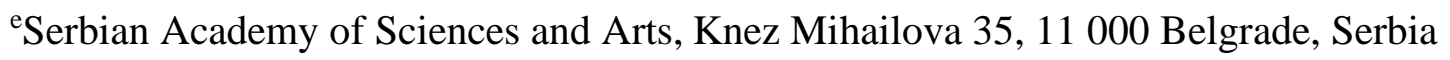

fUniversity of Belgrade - Faculty of Chemistry, Department of Inorganic Chemistry, Studentski $\operatorname{trg}$ 12-16, 11000 Belgrade, Serbia

*Corresponding author: E-mail: sanjag@chem.bg.ac.rs (S. Grgurić-Šipka), Phone: +381-11333-67-42. Fax: +381-11-218-43-30. 


\section{The list of abbreviations}

Cyt - horse heart cytochrome c

Ly - egg-white lysozyme

HESI - heated electrospray ionization

C1 - $\left[\left(\eta^{6}-p\right.\right.$-cymene $\left.) \mathrm{RuL} 1 \mathrm{Cl}\right]$, where L1 is isoquinoline-3-carboxylic acid,

C2 - [( $\eta^{6}-p$-cymene $\left.) \mathrm{RuL} 2 \mathrm{Cl}_{2}\right]$, where L2 is N'-(1-(pyridin-4-yl)ethyliden) octanehydrazide

C3, $\left[\left(\eta^{6}-p\right.\right.$-cymene)RuL3Cl 2$]$, where L3 is N'-(1-(pyridin-3-yl)ethylidene)

hydrazinecarbothioamide,

C4 - [( $\eta^{6}-p$-cymene $\left.) \mathrm{RuL} 4 \mathrm{Cl}\right]$, where L4 is 1-(7-chloroquinolin-4-yl) thiourea 


\begin{abstract}
The reactions of four cymene-capped ruthenium(II) compounds with pro-apaptotic protein, cytochrome c (Cyt), and anti-proliferating protein lysozyme (Ly) in carbonate buffer were investigated by ESI-MS, UV-Vis absorption and CD spectroscopy. The complexes with two chloride ligands (C2 and C3) were more reactive toward proteins than those with only one $(\mathbf{C 1}$ and C4), and the complex with S,N-chelating ligand (C4) was less reactive than one with O,Nchelating ligand (C1). Dehalogenated complexes are most likely species initially coordinating proteins for all tested complexes. During the time, protein adducts vividly exchanged non-arene organic ligand $\mathrm{L}$ with $\mathrm{CO}_{3}{ }^{2-}$ and $\mathrm{OH}^{-}$, while cymene moiety was retained. In water, only dehalogenated adducts were identified suggesting that in vivo, in the presence of various anions, dynamic ligand exchange could generate different intermediate protein species. Although all complexes reduced Cyt, the reduction was not dependent on their reactivity to protein, implying that initially noncovalent binding to Cyt occures, causing its reduction, followed by coordination to protein. Cyt reduction was accompanied with rupture of ferro-Met 80 and occupation of this hem coordination site by a histidine His-33/26. Therefore, in Cyt with $\mathbf{C 2}$ and $\mathbf{C 3}$ less intensive reduction of hem iron leave more unoccupied target residues for $\mathrm{Ru}$ coordination, leading to more efficient formation of covalent adducts, in comparison to $\mathbf{C 1}$ and $\mathbf{C 4}$. This study contribute to development of new protein-targeted $\mathrm{Ru}(\mathrm{II})$ cymene complexes, and to design of new cancer therapies based on targeted delivery of $\mathrm{Ru}(\mathrm{II})$ arene complexes bound on pro-apoptotic/antiproliferating proteins as vehicles.
\end{abstract}

Key words: Ruthenium(II)-cymene complexes; Protein metalation; Anticancer metallodrugs; Mass spectrometry. 


\section{Introduction}

Cis platin and the 2nd and 3rd generation analogues, carboplatin and oxaliplatin, are widely used for treatment of testicular, ovarian, lung, head and neck, as well as colorectal cancer $[1,2]$. However, inherent limitations, such as toxicity to normal cells causing severe side effects and acquired drug resistance, restrict their further wider applications [3]. Therefore, many other transition metal complexes with potential anticancer activity have been developed, with the clear aim to improve pharmacological properties [4]. Ruthenium complexes were identified as one of the alternate classes, due to kinetics of ligand substitution that is similar to platinum complexes, structural diversity and iron mimicking property. In the same time, they demonstrate lower toxicity, good selectivity for tumors, inhibition of the antimetastatic progression and antiangiogenic properties which make them very interesting for drug development.

$\mathrm{Ru}(\mathrm{III}) \quad$ complexes NAMI-A, ([ImH][transRuCl$\left.\left.{ }_{4}(\mathrm{DMSO}) \operatorname{Im}\right]\right)$ and $\mathrm{KP} 1019, \quad[\operatorname{InH}][$ trans$\left.\mathrm{RuCl}_{4} \mathrm{In}_{2}\right]$ successfully completed phase I of clinical trials. Although NAMI-A is the only ruthenium compound to have reached the phase II stage [5], recently it has been withdrawn due to its toxicity profile and the lack of convincing preliminary efficacy results $[6,7]$. It is believed that these ruthenium(III) complexes might be reduced to ruthenium(II) to exert their anticancer effect. With regard to this, a series of the half-sandwich ruthenium(II) based organometallic complexes $([(\eta 6-$ arene $) \mathrm{Ru}(\mathrm{en})(\mathrm{Cl})] \mathrm{PF} 6$, en $=$ ethylenediamine, arene $=$ benzene, pcymene $(1)$, biphenyl (2), tetrahydroanthrance, etc.) have been developed and show promising cytotoxicity both in vitro and in vivo, and even cytotoxicity towards cisplatin-resistant cancer cell lines [811]. As for cisplatin, DNA is a potential target for the $\mathrm{Ru}(\mathrm{II})$ arene complexes, most of which bind selectively to N7 of guanine [12-15]. However, it has been proposed that proteins could play more important roles in the action of ruthenium drugs than in that of platinum drugs [16]. 
One of the mode of action, that is proposed for ruthenium-based compounds, is via protein targets involved in cellular signaling pathways and the histone proteins of nucleosome core particles [17].

As proteins are the first potential binding targets for the complexes in the bloodstream after their intravenous administration, interactions of anticancer therapeutics with proteins are very important to be investigated with aim to elucidate their pharmacokinetic pathways. Several studies investigated the reactivity of organoruthenium compounds towards peptides, like glutathione [1918, 2019], and proteins [20, 21, 22], like eman [21] human [22]. For instance, the RAPTA complexes exhibit a high affinity for protein molecules, favored over DNA binding due to the presence of the hydrophobic arene moiety. In addition, mass spectrometric-based assays reveal that these protein interactions are quite selective, identifying His33 as the preferred binding site in cytochrome c [23]. Analogous studies on other ruthenium-containing complexes, e.g. NAMI-A, implied the same conclusion, and histidine residue have also been shown to be important binding sites for KP1019 [24, 25$]$. Above all, proteins have a crucial role in the transport of metal based drugs, their mode of action, as well as their overall pharmacological and toxicological profiles [26]. All these findings imply how important is to study metal based drugs protein interaction on the route toward discovering of new drug. To this aim a number of analytical techniques, as well as spectroscopic and biophysical methods, are extensively applied to study the reactivity of metal complexes with different biomolecules. The most advanced approach includes characterization of protein adducts of ruthenium anticancer drugs by X-ray crystallography [27-30], by mass spectrometry that has emerged in the last decade as a major tool to characterize the interactions 
of metallodrugs at a molecular level [ $27-31-3035]$, as well as by combined use of mass spectrometry and X-ray crystallography $[36,37]$.

For many cancers current chemotherapies alone are not efficient, requiring alternative therapeutic approaches, and one of the strategies is the exploitation of the proliferation and apoptosis pathways. Therefore, in the last few years pro-apoptotic and anti-proliferating proteins, and their targeted delivery to cancer cells, are gaining importance in cancer therapy. Cytochrome $\mathrm{c}$ is known as pro-apoptotic factor, triggering apoptosome assembly and caspase cascade that eventually lead to cell death. Delivering cytochrome c into the cytoplasm activates apoptosis downstream from many events, and avoidance of apoptosis is a hallmark of cancer. Moreover, cytochrome c significantly increased the levels of apoptosis when combined with clinically used anticancer agents [3138]. On the other hand, lysozyme inhibits invasion and migration of cancer cells [3239], showing an anti-proliferative action against many cancer cell lines [3340]. Due to its ability to enhance the efficacy of chemotherapy treatments, lysozyme is becoming a promising co-adjuvant for anti-cancer therapies [3441].

With the aim to study cytotoxic potential of ruthenium complexes, a series of the half-sandwich ruthenium(II)-cymene complexes, have been developed earlier, $\mathbf{C 1},\left[\left(\eta^{6}-p\right.\right.$-cymene $\left.) \mathrm{RuL} 1 \mathrm{Cl}\right]$ [3542], C2, [( $\eta^{6}-p$-cymene $\left.) \mathrm{RuL2Cl} 2\right], \mathbf{C 3},\left[\left(\eta^{6}-p\right.\right.$-cymene $\left.) \mathrm{RuL}^{6} \mathrm{Cl}_{2}\right][3643]$ and $\mathbf{C 4},\left[\left(\eta^{6}-p-\right.\right.$ cymene)RuL4Cl] [3744], where L1 is isoquinoline-3-carboxylic acid, L2 is N'-(1-(pyridin-4yl)ethyliden) octanehydrazide, L3 is N'-(1-(pyridin-3-yl)ethylidene) hydrazinecarbothioamide and L4 1-(7-chloroquinolin-4-yl) thiourea (Fig 1.). These complexes showed promising in vitro cytotoxicity, even towards cisplatin-resistant cancer cell lines [3542-3744]. To understand a possible mechanism of action of such types of compounds via protein targets, and to investigate their potential as cancer therapeutics in complex with pro-apoptotic and anti-proliferating 
proteins, their interactions with horse heart cytochrome c (Cyt) and egg white lysozyme (Ly) were investigated as model proteins. These two proteins are also common model system for investigation of interactions of proteins with metal-based anticancer compounds by mass spectrometry, due to their low molecular mass [3138]. The interactions were monitored through ESI MS, UV-VIS absorption and CD spectroscopy, where speciation of protein adducts in water solution, with and without other anions (i.e. bicarbonate buffer), was followed, and the complexes differing in mode of ligand coordination and number of chloride anions were compared.

\section{Materials and methods}

\subsection{Materials}

The horse heart cytochrome c was obtained from Sigma (C7752, St. Louis, MO, USA). The chicken egg white lysozyme was isolated and purified from fresh egg white according to a previously published method [3945] and protein purity was assessed by electrophoresis. C1 was prepared according to [3542], $\mathbf{C 2}$ and $\mathbf{C 3}$ as described in [3643], and $\mathbf{C 4}$ following previously published procedure [3744]. The deionized water used in the experiments was purified by a Milli-Q system (Millipore, Molsheim, France).

\subsection{Spectrophotometric and circular dichroism spectra measurements}

The interaction of horse heart cytochrome $\mathrm{c}(10 \mu \mathrm{M})$ with the ruthenium complexes $(30 \mu \mathrm{M})$, was monitored in $20 \mathrm{mM}$ ammonium hydrogen carbonate $\mathrm{pH} 7.4$ at $37{ }^{\circ} \mathrm{C}$, at different time intervals over a period of $48 \mathrm{~h}$ under aerobic conditions and the samples were kept in the dark. UV VIS spectra were recorded on NanoDrop 2000 spectrophotometer (Thermo Fisher Scientific, USA). 
CD spectra were recorded on a JASCO J-815 spectropolarimeter (JASCO, Tokyo, Japan) with protein concentration of $25 \mu \mathrm{M}$, with the ruthenium/protein molar ratio of 3:1 ratio, in $20 \mathrm{mM}$ ammonium hydrogen carbonate $\mathrm{pH} 7.4$ at $25{ }^{\circ} \mathrm{C}$. The spectra were recorded in the range $300-600$ $\mathrm{nm}$ using $1.0 \mathrm{~cm}$ cuvettes. Each spectrum was acquired four times, and the results were averaged.

\subsection{ESI-MS analysis}

The samples were prepared in $20 \mathrm{mM}$ ammonium hydrogen carbonate $\mathrm{pH} 7.4$, with a protein concentration of $100 \mu \mathrm{M}$, and a ruthenium to protein molar ratio of 3:1. The stock solutions of ruthenium complexes were made in methanol, and in final reaction mixture with protein methanol was $4 \%(\mathrm{v} / \mathrm{v})$. The reaction mixtures were incubated for 24 and $48 \mathrm{~h}$ at $37{ }^{\circ} \mathrm{C}$. The samples were extensively ultrafiltered and diluted with MilliQ water 10-fold for Cyt and 20-fold for Ly samples. After the samples were injected directly with flow $10 \mu \mathrm{L} / \mathrm{min}$ ESI-MS spectra were recorded by LTQ Orbitrap XL (Thermo Fisher Scientific Inc., USA) mass spectrometer, equipped with a conventional ESI source. The ionization was done in positive mode on heated electrospray ionization (HESI) probe. HESI parameters were: capillary temperature $275{ }^{\circ} \mathrm{C}$, source voltage $4.2 \mathrm{kV}$, capillary voltage $42 \mathrm{~V}$, tube lens voltage $120 \mathrm{~V}$, vaporizer temperature 50 ${ }^{\circ} \mathrm{C}$, sheath, sweep and auxiliary gas flow rate was set at 15, 0 and 4 (arbitrary units), respectively. Acquisition was 5 minute per sample. MS spectra were acquired between m/z 100 and m/z 2000 . For spectra acquisition a nominal resolution (at $\mathrm{m} / \mathrm{z} 400$ ) of 60000 was used. The ESI-MS data were acquired and deconvoluted with Xcalibur version 2.1 (Thermo Fisher Scientific Inc., USA). 


\section{Results}

\subsection{Interactions of $\mathrm{Ru}(\mathrm{II})$-cymene complexes with lysozyme and cytochrome c monitored by ESI-MS spectroscopy}

In this study we have monitored interactions of $\mathrm{Ru}(\mathrm{II})$ complexes with the proteins in carbonate buffer in order to get more realistic picture, having in mind that carbonate/bicarbonate is obligatory intracellular and extracellular ion present at concentration of about $25 \mathrm{mM}$. Highresolution LTQ-Orbitrap ESI MS was used to monitor the adducts formed between four ruthenium complexes and proteins, Ly and Cyt. Representative deconvoluted ESI-MS spectra of Ly and Cyt incubated with $\mathbf{C 2}$, together with the spectra of the untreated proteins, are presented in Fig. 2 and Fig. 3, respectively. The mass spectra of Ly and Cyt incubated with C1, C2, C3 and $\mathbf{C} 4$ are shown in Figs. S1-S18. The major identified adducts of metal complexes with proteins are given in Table 1, and possible minor adducts are presented in Table S1. In addition, the relative intensity of unmodified and modified proteins was used to roughly estimate extent of protein modification by tested ruthenium complexes (Table S2).

The molecular mass of untreated Ly (Fig. 2) was 14304.9638 Da, while the mass=of untreated Cyt (Fig. 3) was 12358.3970 Da. The mass spectra of both proteins incubated for $24 \mathrm{~h}$ and $48 \mathrm{~h}$ with all tested ruthenium complexes show additional peaks in mass region 14550-14850 Da for Ly (Fig. 2B and C, S2-S10) and 12550-13000 Da for Cyt (Fig. 3B and C, S11-S18).

C1 have similar reactivity with Ly and Cyt, resulting in several adducts with similar ESI MS peak pattern (Figs S2, S6, S11 and S15). The most dominant adduct of C1 with both Ly and Cyt is [RuCymL] (Table 1). In the group of possible minor adducts, the ligands are replaced with $\mathrm{CO}_{3}^{2-}$ and $\mathrm{OH}^{-}$, and several minor adducts are represented as series of consecutive peaks differing in mass for one $\mathrm{OH}^{-}$ligand (Table S1, Figs. S2, S6, S11 and S15). In the case of both 
proteins, bound ligands are relatively stable, reflecting in almost the same peak pattern at both 24 $\mathrm{h}$ and $48 \mathrm{~h}$ (Figs. S2, S6, S11 and S15), suggesting that after initial formation of adducts with C1 further ligand exchange almost does not occur.

According to the relative intensity of adducts, $\mathbf{C 2}$ and $\mathbf{C 3}$ have markedly higher reactivity to Cyt in comparison to Ly, and in comparison to $\mathbf{C} \mathbf{1}$. There are three different main adducts of $\mathbf{C} \mathbf{2}$ and C3 with Ly, [RuCym], $\left[\mathrm{RuCym}\left(\mathrm{CO}_{3}\right)\right]$, and diruthenated adduct with $\left[\mathrm{RuCym}\left(\mathrm{CO}_{3}\right)\right]$ and $\mathrm{Ru}$ metal cation (Table 1). With Cyt only [RuCym] adduct dominates. Here, adduct with retained both cymen and ligand L, i.e. with [RuCymL], was detected only as minor adduct and mostly with C3. In the group of minor adducts ligand exchange for $\mathrm{CO}_{3}{ }^{2-}$ and $\mathrm{OH}^{-}$also took place. The adduct profiles and intensity of Ly are the same for $\mathbf{C} 2$ and $\mathbf{C 3}$ and do not change with time, suggesting that $\mathbf{C} \mathbf{2}$ and $\mathbf{C} \mathbf{3}$ have similar propensity and the rate of ligand exchange (Figs. S3 and S4), and that they are formed within $24 \mathrm{~h}$ and remain stable for $48 \mathrm{~h}$ (Figs. S3, S4, S7 and S8). Cyt adducts profiles and intensity are similar for $\mathbf{C 2}$ and $\mathbf{C 3}$, analogously to Ly (Figs. S12 and S13). However, adducts profile of Cyt change with time, including formation of new, as well as adducts with concomitant increase in modification extent (Figs. S12, S13, S16 and S17), implying that dynamic ligand exchange takes place after initial formation of adducts. For $\mathbf{C 3}$ considerable quantity of new minor adducts are formed, even at some expense of decrease in the major adduct [RuCym] (Tables 1 and S1), indicating even more vivid ligand exchange between 24 and $48 \mathrm{~h}$ of incubation. It is evident that Cyt is noticeably more prone to modification by $\mathbf{C 2}$ and $\mathbf{C} 3$ than Ly, and that modification extent increase with the time (Table S2), but in modified Cyt species ligand exchange continuously takes place, implying possible subtle conformational changes of this protein in the presence of $\mathbf{C} 2$ and $\mathbf{C 3}$. 
C4 demonstrated the least reactivity toward investigated proteins. The most dominant adducts with Ly were $[\mathrm{RuCym}],\left[\operatorname{RuCym}\left(\mathrm{CO}_{3}\right)\right]$, and one diruthenated adduct with $\left[\mathrm{RuCym}\left(\mathrm{CO}_{3}\right)\right]$ and Ru cation, while with Cyt, $[\mathrm{RuCym}]$ and $[\mathrm{RuCymL}]$ adducts are the major ones (Table 1$)$. Only the traces of Ly adducts are present after $24 \mathrm{~h}$, and after $48 \mathrm{~h}$ extent of modification rises to the level reached by other complexes, on account of increase in the intensity of three initially formed adducts (Figs. S5 and S9). This suggests that binding of $\mathbf{C 4}$ to Ly is kinetically less favored than binding of other three complexes. The adducts profile of Cyt does not change with time significantly, but $[\mathrm{RuCymL}]$ adduct almost disappears and several minor adducts increase (Figs. S14 and S18), resulting in slight total increase in modification extent. This also pointed to the slow reactivity of $\mathbf{C} \mathbf{4}$ to $\mathrm{Cyt}$, as the signal intensity of initially formed adducts increase with the time without formation of new adducts, implying that dynamic ligand exchange takes place after initial formation of adducts.

In both proteins, [RuCymL] adducts were detected as major adduct with $\mathbf{C} \mathbf{1}$ at both time periods, and with $\mathbf{C 4}$ after $24 \mathrm{~h}$, while they could be detected only as minor adduct with $\mathbf{C 2}$ and $\mathbf{C 3}$. This indicates that $[\mathrm{RuCymL}]$ is most likely species initially coordinating the protein for all tested complexes. However, in=C1 ligand L remains during the time due to almost absence of ligand exchange, while for $\mathbf{C 4}$, and especially for $\mathbf{C 2}$ and $\mathbf{C 3}$, due to the vivid ligand exchange with $\mathrm{CO}_{3}{ }^{2-}$ and $\mathrm{OH}^{-},[\mathrm{RuCymL}]$ adduct is transformed into carbonato/hydroxo complexes. This also suggests that ligand exchange dynamics of protein-bound complexes is $\mathbf{C 2}, \mathbf{C 3}>\mathbf{C 4}>\mathbf{C 1}$.

In the most of studies, investigating interaction of Ru complexes with proteins by ESI-MS, the reaction mixtures were prepared in water [ $2831,4946-4551]$, consequently not taking into account possible effects of biological anions on these interactions. Therefore, in order to compare interactions of Cyt with $\mathbf{C 3}$ and $\mathbf{C 4}$ in water with those in carbonate buffer, ESI-MS 
spectra of Cyt incubated with $\mathbf{C 3}$ and $\mathbf{C} 4$ for $48 \mathrm{~h}$ were recorded (Fig. S19-S21, Table S4). In contrast to the samples incubated in carbonate buffer, only [RuCym] adducts of Cyt were identified, suggesting that in vivo, in the presence of various anions, such as carbonate, phosphate, sulphate and a series of organic acids anions, dynamic ligand exchange could be expected generating different intermediate protein species.

\subsection{Interactions of Ru(II)-cymene complexes with cytochrome c monitored by UV-Vis absorption spectroscopy}

In order to get better insight into interactions of Cyt with Ru(II)-cymene complexes, UV-Vis spectra of Cyt, after $24 \mathrm{~h}$ and $48 \mathrm{~h}$ of incubation in the presence and in the absence of C1, C2, $\mathbf{C 3}$ and C4, were monitored (Figs. 4, S22-S30). After $24 \mathrm{~h}$ in the visible region of unmodified Cyt, two absorbance peaks of at $530 \mathrm{~nm}$ and $410 \mathrm{~nm}$ can be observed, typical for this protein in its oxidized form $\left(\mathrm{Fe}^{3+}\right)$. Upon addition of ruthenium complexes, the appearance of peak at 550 $\mathrm{nm}$, along with shift of peak from 530 to $521 \mathrm{~nm}$, indicates partial reduction of heme iron, even under aerobic conditions. In comparison to $\mathbf{C 2}$ and $\mathbf{C 3}$, the presence of $\mathbf{C 1}$ resulted in higher heme iron reduction, and $\mathbf{C 4}$ induced iron reduction to dramatic extent. After $48 \mathrm{~h}$ unmodified Cyt was slightly reduced, probably due to some photoreduction during spectra recording, as oxygen concentration was lower after $48 \mathrm{~h}$ than after $6 \mathrm{~h}$ or $24 \mathrm{~h}$ incubation. However, all tested complexes resulted in pronounced hem reduction after $48 \mathrm{~h}$, with the most dramatic one induced by $\mathbf{C 4}$. C1, C2 and $\mathbf{C 3}$ induce progressive hem reduction during the $48 \mathrm{~h}$, while heme reduction by $\mathbf{C} \mathbf{4}$ reached its maximum already after $6 \mathrm{~h}$.

\subsection{Interactions of $\mathrm{Ru}(\mathrm{II})$-cymene complexes with cytochrome c monitored by $\mathrm{CD}$ spectroscopy}


The CD spectra of the heme group in Cyt can be used to monitor the changes in its state, as well as the changes in tertiary structure around the heme moiety [4652]. Therefore, CD spectra of Cyt-ruthenium complexes adducts were recorded in Soret region (Figs. 5 and S31). Due to a Cotton effect, CD spectrum of native ferric Cyt in the Soret region has a bisignate band shape, with the positive band at $406 \mathrm{~nm}$ and the negative band at $416 \mathrm{~nm}$, assigned to interactions between heme and the polypeptide backbone of the heme crevice. The interaction of all tested complexes with Cyt has resulted in decrease in positive CD signal at $406 \mathrm{~nm}$, and the increase in negative signal at $416 \mathrm{~nm}$, with appearance of signal at $425 \mathrm{~nm}$. The decrease of maximum at $406 \mathrm{~nm}$ with generation of peak at $425 \mathrm{~nm}$ is characteristic of ferrocytochrome [4652], suggesting that all complexes reduced heme iron to some extent. The most pronounced effect was observed after incubation with $\mathbf{C 1}$ after $24 \mathrm{~h}$. After $48 \mathrm{~h}$ of incubation the extent of iron reduction did not change for $\mathbf{C 1}, \mathbf{C} 2$ and $\mathbf{C 3}$, while $\mathbf{C 4}$ caused dramatic reduction of iron between 24 and $48 \mathrm{~h}$ of incubation, with remarkable decrease of maximum at $406 \mathrm{~nm}$, increase in generated peak at $425 \mathrm{~nm}$ and increase in minimum at $416 \mathrm{~nm}$. The decrease and red shift in 406 $\mathrm{nm}$ maximum and the increase in $416 \mathrm{~nm}$ minimum was also noticed due to of interaction of trans-indazolium(bisindazole)tetrachlororuthenate(III) with Cyt [4753].

In the native state of ferrous Cyt, heme iron is ligated by His18 and Met80. The forms of Cyt, known to have the hem iron-Met80 coordination bond disrupted, lack ef the $416 \mathrm{~nm}$ dichroic band, and therefore $416 \mathrm{~nm}$ band is the evidence for the axial bond between heme iron and Met80 [4854]. Similarly, the intensity of peak at $416 \mathrm{~nm}$ decreases with Cyt unfolding and the loss of integrity of the heme crevice [4652]. According to this, decrease in intensity of signal at $416 \mathrm{~nm}$ due to binding of tested complexes, especially dramatic in the case of $\mathbf{C} 4$ after $48 \mathrm{~h}$ of 
incubation, suggests that the portion of Cyt molecules have changed heme crevice with disrupted hem iron-Met 80 bond.

\section{Discussion}

Having in mind that the success of a chemotherapy drug is strictly connected to its effectiveness against tumor metastases rather than against the primary lesions [6], Ru complexes showing antimetastatic activity are promising chemotherapeutics. As Ru complexes having anti-metastatic activity mainly target proteins [4248], investigation their interactions with proteins are essential to figure out still unclear mechanisms of their action.

In this study interactions of four half-sandwich ruthenium(II)-cymene complexes, C1, C2, C3 and $\mathbf{C 4}$, with anti-proliferating protein lysozyme and anti-apoptotic protein cytochrome c, as model proteins were investigated. MS spectra demonstrated that all tested complexes formed covalent adducts with both proteins, and dehalogenated complexes were most likely species initially coordinating the proteins. However, during incubation time vivid ligand exchange of non-arene organic ligand $\mathrm{L}$ with $\mathrm{CO}_{3}{ }^{2-}$ and $\mathrm{OH}^{-}$occurred, resulting in transformation of proteinbound dehalogenated complexes into carbonato/hydroxo complexes with retained cymene moiety. The complexes $\mathbf{C 2}$ and $\mathbf{C 3}$ have shown higher reactivity toward proteins, and ligand L exchange of their protein adducts was more dynamics, in comparison to $\mathbf{C 1}$ and $\mathbf{C 4}$ complexes. The differences in ligand exchange dynamics of protein-bound complexes and the efficiency of adduct formation is due to intrinsic differences in the ability of tested complexes to release their leaving groups and react with protein side chains. $\mathbf{C 2}$ and $\mathbf{C 3}$ are complexes containing ligands coordinated in a monodentate manner and two $\mathrm{Cl}^{-}$ligands, that can be readily substituted by $\mathrm{H}_{2} \mathrm{O} / \mathrm{OH}^{-}$, and therefore capable to more efficiently react with proteins (Fig. 1). However, $\mathbf{C 1}$ has 
shown to be slightly more reactive to proteins than $\mathbf{C 4}$. This can be explained by $\mathrm{O}, \mathrm{N}$-chelated bidentate ligand in $\mathbf{C 1}$ and $\mathrm{S}, \mathrm{N}$-chelated bidentate ligand in $\mathbf{C 4}$. It was reported that $\mathrm{Ru}(\mathrm{II})-$ cymene complexes, bearing pyronato and pyridonato (O,O-chelating) ligands, reacted readily with the model protein ubiquitin, in contrast to complexes with thiopyronato (S,O-chelating) ligand, which reacted only to a minor degree [4248].

The chloride ligands are lost due to rapid aquation of all tested complexes in aqueous solutions [8], while cymene moiety is retained in all adducts with both protein. This is in accordance to literature data reporting the maintenance of arene moiety in protein adducts of arene- $\mathrm{Ru}(\mathrm{II})$ complexes, with arene stabilizing metal center and preventing rapid oxidation of the $\mathrm{Ru}(\mathrm{II})$ to $\mathrm{Ru}(\mathrm{III})$ [4955]. The fraction of adducts of all complexes contain bis-ruthenium adducts, indicating the existence of several available Ru binding sites on both proteins. The most of minor adducts of all tested complexes contain coordinated bicarbonate ion, also observed upon binding of RAPTA-T to transferrin in bicarbonate buffer [5056]. The series of minor adducts of all investigated complexes, with different number of coordinated $\mathrm{HCO}_{3}{ }^{2-}$ and $\mathrm{OH}^{-}$are formed by decarboxylation of bicarbonato complex to its hydroxo form. It should be mentioned that the complex can be in carbonato form, or it can protonate to its bicarbonate form, depending on the $\mathrm{pH}$ and the $\mathrm{pKb}$ for the protonation of the bound carbonato ligand. It seems that, similarly to platinum anticancer drugs, tested Ru complexes behave according to multistage rocket model [6], where leaving ligands ( $\mathrm{Cl}$ - and organic ligands $\mathrm{L}$ ) dissociate along the pathway to the target, while supporting ligand (Cym) remains bound to the metal and thus could contribute to tune its action.

Interestingly, our previous studies determined $\mathrm{IC}_{50}$ for cytotoxic effects toward $\mathrm{HeLa}$ and $\mathrm{A} 549$ cell lines for $\mathbf{C 2}(85.38$ and $90.67 \mathrm{uM})$ and $\mathbf{C 3}(87.43$ and $87.82 \mathrm{uM})$ [3643] is higher than one 
of C1 (45.35 and 25.76 uM) [3542] and C4 (56.45 and 31.49 uM) [3744]. These results are in accordance to inverse correlation between cytotoxic potency of the Ru-cymene compounds and the extent of protein adduct formation observed by Meier et al. [4248]. The authors explained this phenomenon by the fact that extensive protein binding accounts for a possible deactivation pathway of $\mathrm{Ru}^{\mathrm{II}}$-type metallodrugs, while low protein binding implies high stability toward biological nucleophiles, resulting in an increased probability that the drug reaches target in its active form. It was demonstrated that RAPTA-C, containing one monodentate ligand and two chlorides, is mainly protein targeting complex with low cytotoxicity, while RAED C, containing bidentate ligand and one two chloride, is mainly DNA targeting complex with high cytotoxic potential [17]. According to observed higher reactivity to proteins observed in this study and lower cytotoxic activity of $\mathbf{C 2}$ and $\mathbf{C 3}$, in comparison to $\mathbf{C 1}$ and $\mathbf{C 4}$, in analogy to RAPTA-C and RAED C, it seems that $\mathbf{C 2}$ and $\mathbf{C 3}$ are more protein targeting and $\mathbf{C 1}$ and $\mathbf{C 4}$ more DNA targeting. C1 is the only one of tested complexes which gave the same major adduct for both proteins and the adduct contained bonded ligand L, similarly to RAPTA-C [2831]. Also, all tested complexes have shown lower reactivity toward Ly compared to Cyt, as was revealed for RAPTA-C complex [2831].

The ruthenium(II) compounds show a high selectivity for cysteine, methionine and histidine. For RuII- $\eta^{6}$-(cymene) complexes, such as RAPTA-C, in Cyt, His33 is the major interaction site [Z831], while in Ly His15 side chain is the preferred binding site of $\mathrm{Ru}^{\mathrm{II}} \eta^{6}$-arene complexes, such as $\mathrm{Ru}_{2}\left(\eta^{6} \text {-benzene }\right)_{2} \mathrm{Cl}_{4}[5157,5258]$ and $\mathrm{Ru}(\mathrm{II})\left(\eta^{6}\right.$-p-cymene $) \mathrm{Cl}_{2}\left(\mathrm{H}_{2} \mathrm{O}\right)$ [27]. Therefore, the most likely sites of binding of complexes tested in this study are His15 in Ly and His33 in Cyt. 
All tested complexes induced heme iron reduction in Cyt. However, heme reduction was higher in the presence of $\mathbf{C 1}$, and especially $\mathbf{C 4}$, in comparison to $\mathbf{C 2}$ and $\mathbf{C} \mathbf{3}$ complexes. Observed iron reduction is in the accordance with spectrophotometric effects on Cyt produced by other ruthenium (II)-cymene compounds, such as RAPTA-C and carbo-RAPTA [2831] and NAMI-A [4046]. Recently, Tamasi et al. [5359] have also observed Cyt reduction by $f a c-\left[\mathrm{Ru}^{\mathrm{II}}(\mathrm{CO})_{3} \mathrm{Cl}_{2} \mathrm{~L}\right]$ complexes, and hypothesized that Cyt reduction is the consequence of ruthenium binding to a specific protein site, capable of modulating the redox properties of the heme center. However, as $\mathbf{C} \mathbf{1}$ and $\mathbf{C} 4$ gave notably lower yield of adducts with Cyt in comparison to $\mathbf{C 2}$ and $\mathbf{C 3}$ (Table 1), prominent reducing activity of $\mathbf{C 1}$, and especially $\mathbf{C 4}$, is actually consequence of their noncovalent interactions with protein. Indeed, in UV region presence of $\mathbf{C 4}$ induce notable blue shift of maximum from $280 \mathrm{~nm}$ to $275 \mathrm{~nm}$, suggesting more polar environment around Tyr and Trp residues and supporting noncovalent interactions of $\mathbf{C 4}$ in the vicinity of Tyr/Trp residues. These results also suggest that Cyt reduction does not necessarily depend on coordinative binding of ruthenium to protein, and it seems that complexes initially bind to Cyt noncovalently, causing its reduction, following by coordination to protein. Although all tested complexes have rutheniumcymene scaffold, it is obvious that ligand $\mathrm{L}$ determines target sites on protein for noncovalent complex binding thus modulating possibility and extent of Cyt reduction. This implies that coordinative binding of tested complexes could be at different sites on protein. The semiquantitative analysis of the observed spectral changes at $550 \mathrm{~nm}$ have shown that about $70 \%$ of the heme iron(III) undergoes reduction to iron(II) already $6 \mathrm{~h}$ after incubation of Cyt with $\mathbf{C 4}$ and remains stable until $48 \mathrm{~h}$ of incubation. Based on analyses of mass spectra, heme reduction was not accompanied by oxidation of protein amino acid residues. Casini et al. also observed Cyt reduction with NAMI-A (about $60 \%$ ) [4946] and RAPTA-C (about $30 \%$ ) [2831]. Mechanism 
of Cyt reduction by Ru complexes still remains unclear. Casini et al. [4946] assumed that reduction is mediated by ruthenium binding to a specific protein-binding site significantly affecting the redox behavior of $\mathrm{Cyt}$, but electron transfer (direct or indirect) from Ru center to heme $\mathrm{Fe}^{3+}$ could not be excluded. Although the reduction potentials of $\mathrm{Fe}^{3+/ 2+}$ in heme of Cyt $\left(0.26 \mathrm{~V}\right.$ vs.NHE) [5460] and free $\mathrm{Ru}^{3+/ 2+}\left(0.25\right.$ vs.NHE) are similar, within a complex $\mathrm{Ru}^{3+/ 2+}$ reduction potential is determined by ligand environment and coordination geometry, and electrochemical properties of Ru complexes can be tuned by variation of the ligands [5561]. In our four tested $\mathrm{Ru}$ complexes, different electronic net donation from the ligands $\mathrm{L}$ and chlorides to the metal center; probably result in different kinetics and thermodynamics of electron transfer from $\mathrm{Ru}^{2+}$ to heme $\mathrm{Fe}^{3+}$. Indeed, similar influence of similar ligand on $\mathrm{Ru}^{3+/ 2+}$ reduction potential in $\mathbf{C 2}$ and $\mathbf{C 3}$ can be observed in the extent of Cyt reduction in the presence of these complexes. The heme iron reduction in the presence of ruthenium complexes was also confirmed by $\mathrm{CD}$ spectra in the Soret region, with the most pronounced effect of $\mathbf{C 3}$ and $\mathbf{C 4}$ complexes. In addition, it seems that, due to ruthenium complexes binding, the portion of Cyt molecules have changed heme crevice with disrupted hem iron-Met 80 bond. In the unfolded state of Cyt, the iron center is axially ligated by the imidazoles of two histidines, the native His 18, and either His26 or His33, which replaces the native axial ligand, Met80 [5662]. Droghetti et al. [5763] identified folded, but nonnative states of ferrous Cyt species, in which the native Met 80 ligand is exchanged with a histidine (His33 or His26). Based on all this, noncovalent interactions of all tested complexes with Cyt resulted in some reduction of heme and slight tertiary structure change as consequence of the rupture of iron (II)-Met 80 and occupation of this coordination site by a histidine His33/26. According to Cyt unfolding mechanism [5864], heme ligand exchange occurs while the protein is still compact. Indeed, charge state distributions of the Cyt modified 
by tested complexes exhibit the same bell-shaped curve as corresponding native Cyt, with the same maximum at $\mathrm{z}=8+$ (not shown), suggesting no significant change in tertiary structure, reflecting in absence of additional exposure of protonable groups to the solvent. Therefore, in $\mathbf{C 2}$ and $\mathbf{C 3}$ less intensive reduction of heme iron leaves more unoccupied His33/26, which are the main targets for $\mathrm{Ru}$ coordination, leading to more efficient formation of covalent adducts in comparison to $\mathbf{C} 1$ and $\mathbf{C 4}$.

Therefore, in the presence of $\mathbf{C 1}$ and $\mathbf{C 4}$ more intensive reduction of heme iron results in the higher extent of iron-Met 80 bond disruption. Consequent higher level of Met 80 ligand exchange with His33/His26 blocks His, which is necessary for Ru coordination, leading to less efficient formation of covalent adducts, in comparison to the presence of $\mathbf{C} \mathbf{2}$ and $\mathbf{C 3}$.

Cyt itself is recognized as promising potent and selective anticancer drug due to its as proapoptotic action, and its targeted delivery to cancer cells, followed by its smart release into the cytoplasm, becomes in the focus these years. Targeted delivery of Cyt, resulting in effective apoptosis of cancer cells, was achieved by encapsulation into ferritin [5965] or polymer nanoparticles [6966, 6167], cross-linking with transferrin [6268], conjugation with lipidapolipoprotein nanoparticles [6369] and immobilization in silica nanoparticles [6470]. Therefore, Cyt derivatives of $\mathrm{Ru}(\mathrm{II})$ complexes tested in this study, especially $\mathbf{C 2}$ and $\mathbf{C 3}$, have potential as therapeutics for cancer treatment from two reasons. On one hand, the tested complexes could be targeted delivered to cancer cells in the form of Cyt derivatives, providing their higher selectivity and efficiency. On the other hand, by binding of tested complexes, Cyt could act as more efficient pro-apoptotic agent, due to synergistic pro-apoptotic action of both Cyt and bound complexes. 


\section{Conclusion}

In general, according to results of this study, it could be concluded that interactions of $\mathrm{Ru}(\mathrm{II})$ complexes with proteins, beside coordinative binding, include their noncovalent interactions and, in the case of heme-proteins like Cyt, heme reduction. In heme proteins, noncovalent binding, and consequent heme reduction, could determine protein reactivity toward $\mathrm{Ru}$ (II) complexes. This study demonstrates that the reactivity of $\mathrm{Ru}(\mathrm{II})$ cymene complexes depends on the number of aquation prone-chloride ligands, and the complexes with $\mathrm{O}, \mathrm{N}$-chelated bidentate ligands are more reactive than one with S,N-chelated ligands. Therefore, these results could serve as guide in further development of protein-targeted $\mathrm{Ru}(\mathrm{II})$ cymene complexes.

The presence of other possible metal-binding ligands, like in extracellular or intracellular milieu, modulates these interactions by ligand exchange, resulting in series of different adducts. In the cells there are many strong metal binding ligands present in $\mathrm{mM}$ concentrations, including carbonate ions. Their ability for exchange, e.g. to bind and to leave, determinate the extent, as well as mechanism of the binding of ruthenium complexes to the target biomacromolecules. Therefore, in searching for $\mathrm{Ru}(\mathrm{II})$ complexes mechanism of action, investigation of ligand exchange of $\mathrm{Ru}(\mathrm{II})$ complexes is important, not only to identify possible reactive $\mathrm{Ru}(\mathrm{II})$ species interacting with proteins, but also to monitor further destiny of their protein adducts in different biological compartments.

Although the protein reactivity toward $\mathrm{Ru}(\mathrm{II})$ complexes is determined by protein structure and ligands in $\mathrm{Ru}(\mathrm{II})$ coordination sphere, this reactivity should be described from both kinetics and stability aspect. Interaction between proteins and $\mathrm{Ru}(\mathrm{II})$ complex can be thermodynamically favored, but also slow, allowing $\mathrm{Ru}(\mathrm{II})$ complex to reach and interact with its target, such as DNA or nuclear proteins. On the other hand, stability of formed protein adducts with $\mathrm{Ru}(\mathrm{II})$ 
complex determine whether it remains blocked with non-target protein, or become available to its targets.

Besides, the obtained results open the possibility for design of new therapies for treating cancers, based on $\mathrm{Ru}(\mathrm{II})$ arene complexes bound on pro-apoptotic proteins as vehicles. Their targeted delivery to cancer cell cytoplasm would enable higher selectivity and efficiency of bound $\mathrm{Ru}(\mathrm{II})$ complexes, while bound $\mathrm{Ru}(\mathrm{II})$ complexes could enhance pro-apoptotic effects of proteins.

\section{Acknowledgements}

This work was supported by the Ministry of Education, Science and Technological Development of the Republic of Serbia, grant numbers 172024 and 172035. The project leading to this application has received funding from the European Union's Horizon 2020 research and innovation programme under grant agreement No 810752. The EC does not share responsibility for the content of the article.

\section{Conflicts of interest}

There are no conflicts to declare.

\section{ORCID}

Sanja Grguric-Sipka: 0000-0003-1906-535X

Tanja Cirkovic Velickovic: 0000-0003-2559-5234

Dragana Stanic-Vucinic: 0000-0003-2576-3074

Stefan Nikolic: 0000-0002-0164-134X

Jelena Mihailovic: 0000-0003-0562-0447 


\section{References}

1 D. Wang and S. J. Lippard (2005) Nat Rev Drug Discov 4:307-320

2 R. F. Ozols (1991) Cancer Treat Rev 18 Suppl A:77-83

3 C. A. Rabik and M. E. Dolan (2007) Cancer Treat Rev 33:9-23

$4 \quad$ S. H. van Rijt and P. J. Sadler (2009) Drug Discov Today 14:1089-1097

$5 \quad$ P. Y. Zhang and P. J. Sadler (2017) Eur J Inorg Chem 2017(12):1541-1548

6 E. Alessio (2017) Eur J Inorg Chem 2017(12):1549-1560

7 S. Leijen, S. A. Burgers, P. Baas, D. Pluim, M. Tibben, E. van Werkhoven, E. Alessio, G. Sava, J. H. Beijnen and J. H. M. Schellens (2015) Invest New Drug 33:201-214

8 F. Y. Wang, A. Habtemariam, E. P. L. van der Geer, R. Fernandez, M. Melchart, R. J. Deeth, R. Aird, S. Guichard, F. P. A. Fabbiani, P. Lozano-Casal, I. D. H. Oswald, D. I. Jodrell, S. Parsons and P. J. Sadler (2005) P Natl Acad Sci USA 102:18269-18274

9 R. E. Morris, R. E. Aird, P. D. Murdoch, H. M. Chen, J. Cummings, N. D. Hughes, S. Parsons, A. Parkin, G. Boyd, D. I. Jodrell and P. J. Sadler (2001) J Med Chem 44:36163621

10 R. E. Aird, J. Cummings, A. A. Ritchie, M. Muir, R. E. Morris, H. Chen, P. J. Sadler and D. I. Jodrell (2002) Brit J Cancer 86:1652-1657

11 A. A. Nazarov, C. G. Hartinger and P. J. Dyson (2014) J Organomet Chem 751:251-260

12 H. M. Chen, J. A. Parkinson, S. Parsons, R. A. Coxall, R. O. Gould and P. J. Sadler (2002) J Am Chem Soc 124:3064-3082

13 H. M. Chen, J. A. Parkinson, R. E. Morris and P. J. Sadler (2003) J Am Chem Soc 125:173-186

14 H. K. Liu, S. J. Berners-Price, F. Y. Wang, J. A. Parkinson, J. J. Xu, J. Bella and P. J. Sadler (2006) Angew Chem Int Edit 45:8153-8156

15 O. Novakova, J. Kasparkova, V. Bursova, C. Hofr, M. Vojtiskova, H. M. Chen, P. J. Sadler and V. Brabec (2005) Chem Biol 12:121-129

16 A. R. Timerbaev, C. G. Hartinger, S. S. Aleksenko and B. K. Keppler (2006) Chem Rev 106:2224-2248 
17 Z. Adhireksan, G. E. Davey, P. Campomanes, M. Groessl, C. M. Clavel, H. J. Yu, A. A. Nazarov, C. H. F. Yeo, W. H. Ang, P. Droge, U. Rothlisberger, P. J. Dyson and C. A. Davey (2014) Nat Commun 5: Art. No. 3462

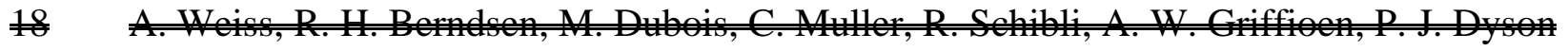
alP. Sliwing (2014) Chem Sei 5:4742-4748

198 F. Y. Wang, J. J. Xu, A. Habtemariam, J. Bella and P. J. Sadler (2005) J Am Chem Soc 127:17734-17743

2019 F. Y. Wang, S. Weidt, J. J. Xu, C. L. Mackay, P. R. R. Langridge-Smith and P. J. Sadler (2008) J Am Soc Mass Spectr 19:544-549

20 A. Merlino (2016) Coordin Chem Rev 326:111-134

21 L. Messori and A. Merlino (2017) Chem Commun 53:11622-11633

22 A. R. Simovic, R. Masnikosa, I. Bratsos and E. Alessio (2019) Coordin Chem Rev 398

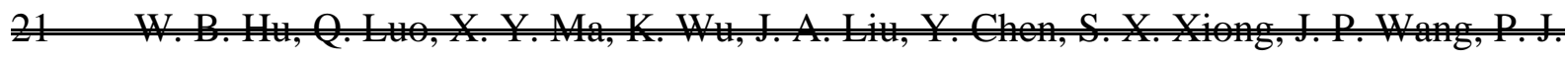
SalleandF.Y.Wang (2009) Chem-Eur J 15:6586-6594

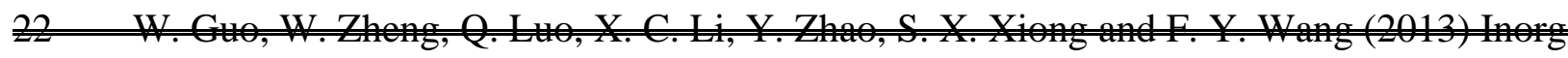
Chem $52.5328-5338$

23 W. H. Ang, A. Casini, G. Sava and P. J. Dyson (2011) J Organomet Chem 696:989-998

24 A. Bergamo, L. Messori, F. Piccioli, M. Cocchietto and G. Sava (2003) Invest New Drug 21:401-411

25 F. Piccioli, S. Sabatini, L. Messori, P. Orioli, C. G. Hartinger and B. K. Keppler (2004) J Inorg Biochem 98:1135-1142

26 A. de Almeida, B. L. Oliveira, J. D. G. Correia, G. Soveral and A. Casini (2013) Coordin Chem Rev 257:2689-2704

27 I. W. McNae, K. Fishburne, A. Habtemariam, T. M. Hunter, M. Melchart, F. Y. Wang, M. D. Walkinshaw and P. J. Sadler (2004) Chem Commun 2004:1786-1787

28 A. Bijelic, S. Theiner, B. K. Keppler and A. Rompel (2016) J Med Chem 59:5894-5903

29 S. Ciambellotti, A. Pratesi, M. Severi, G. Ferraro, E. Alessio, A. Merlino and L. Messori (2018)

30 J. Hildebrandt, H. Gorls, N. Hafner, G. Ferraro, M. Durst, I. B. Runnebaum, W. Weigand and A. Merlino (2016) Dalton T 45:12283-12287 
2831 A. Casini, G. Mastrobuoni, W. H. Ang, C. Gabbiani, G. Pieraccini, G. Moneti, P. J. Dyson and L. Messori (2007) ChemMedChem 2:631-635

2932 A. Casini, C. Gabbiani, E. Michelucci, G. Pieraccini, G. Moneti, P. J. Dyson and L. Messori (2009) J Biol Inorg Chem 14:761-770

3033 M. Wenzel and A. Casini (2017) Coordin Chem Rev 352:432-460

34 L. Biancalana, A. Pratesi, F. Chiellini, S. Zacchini, T. Funaioli, C. Gabbiani and F. Marchetti (2017) New J Chem 41:14574-14588

35 Y. P. Sheng, Z. H. Hou, S. Y. Cui, K. M. Cao, S. M. Yuan, M. Sun, J. Kljun, G. M. Huang, I. Turel and Y. Z. Liu (2019) Chem-Eur J 25:12789-12794

36 G. Ferraro, T. Marzo, M. E. Cucciolito, F. Ruffo, L. Messori and A. Merlino (2019) Int J Mol Sci 20

37 A. Merlino, T. Marzo and L. Messori (2017) Chem-Eur J 23:6942-6947

3138 W. Al-Shakarchi, A. Alsuraifi, M. Abed, M. Abdullah, A. Richardson, A. Curtis and C. Hoskins (2018) Pharmaceutics 10(2): Art. No. 48

3239 H. Y. Wang, J. H. Guo, W. J. Lu and Z. J. Feng (2016) Int J Clin Exp Patho 9:8239-8246

3340 M. I. Khan, D. Dowarha, R. Katte, R. H. Chou, A. Filipek and C. Yu (2019) Plos One 14(5): Art. No. e0216427

3441 B. Hernandez-Ledesma and C. C. Hsieh (2017) Crit Rev Food Sci 57:2358-2376

3542 I. Ivanovic, K. K. Jovanovic, N. Gligorijevic, S. Radulovic, V. B. Arion, K. S. A. M. Sheweshein, Z. L. Tesic and S. Grguric-Sipka (2014) J Organomet Chem 749:343-349

3643 I. Ivanovic, N. Gligorijevic, S. Arandelovic, S. Radulovic, A. Roller, B. K. Keppler, Z. L. Tesic and S. Grguric-Sipka (2013) Polyhedron 61:112-118

3744 S. Nikolic, D. M. Opsenica, V. Filipovic, B. Dojcanovic, S. Arandelovic, S. Radulovic and S. Grguric-Sipket (2015) Organometallics 34:3464-3473

38 X.J.Jiang X.D.Wang (2004) Anm Rev Biomem 73:87 106

3945 D. A. Omana, J. P. Wang and J. P. Wu (2010) J Chromatogr B 878:1771-1776

4046 A. Casini, G. Mastrobuoni, M. Terenghi, C. Gabbiani, E. Monzani, G. Moneti, L. Casella and L. Messori (2007) J Biol Inorg Chem 12:1107-1117

4147 C. G. Hartinger, A. Casini, C. Duhot, Y. O. Tsybin, L. Messori and P. J. Dyson (2008) J Inorg Biochem 102:2136-2141 
4248 S. M. Meier, M. Hanif, W. Kandioller, B. K. Keppler and C. G. Hartinger (2012) J Inorg Biochem 108:91-95

4349 C. Scolaro, A. B. Chaplin, C. G. Hartinger, A. Bergamo, M. Cocchietto, B. K. Keppler, G. Sava and P. J. Dyson (2007) Dalton T 43:5065-5072

4450 F. Y. Wang, J. Bella, J. A. Parkinson and P. J. Sadler (2005) J Biol Inorg Chem 10:147155

4551 R. H. Wills, A. Habtemariam, A. F. Lopez-Clavijo, M. P. Barrow, P. J. Sadler and P. B. O'Connor (2014) J Am Soc Mass Spectr 25:662-672

4652 Y. G. Thomas, R. A. Goldbeck and D. S. Kliger (2000) Biopolymers 57:29-36

4753 L. Trynda-Lemiesz (2004) Acta Biochim Pol 51:199-205

4854 R. Santucci and F. Ascoli (1997) J Inorg Biochem 68:211-214

4955 A. Habtemariam, M. Melchart, R. Fernandez, S. Parsons, I. D. Oswald, A. Parkin, F. P. Fabbiani, J. E. Davidson, A. Dawson, R. E. Aird, D. I. Jodrell and P. J. Sadler (2006) J Med Chem 49:6858-6868

5056 M. Groessl, M. Terenghi, A. Casini, L. Elviri, R. Lobinski and P. J. Dyson (2010) J Anal Atom Spectrom 25:305-313

5157 H. Tabe, S. Abe, T. Hikage, S. Kitagawa and T. Ueno (2014) Chem-Asian J 9:1373-1378

5258 S. Abe and T. Ueno (2015) Rsc Adv 5:21366-21375

5359 G. Tamasi, A. Merlino, F. Scaletti, P. Heffeter, A. A. Legin, M. A. Jakupec, W. Berger, L. Messori, B. K. Keppler and R. Cini (2017) Dalton T 46:3025-3040

5460 K. M. Yocom, J. B. Shelton, J. R. Shelton, W. A. Schroeder, G. Worosila, S. S. Isied, E. Bordignon and H. B. Gray (1982) Proc Natl Acad Sci U S A 79:7052-7055

5561 E. Reisner, V. B. Arion, B. K. Keppler and A. J. L. Pombeiro (2008) Inorg Chim Acta 361:1569-1583

5662 F. A. Tezcan, J. R. Winkler and H. B. Gray (1998) J Am Chem Soc 120:13383-13388

5763 E. Droghetti, S. Oellerich, P. Hildebrandt and G. Smulevich (2006) Biophysical journal 91:3022-3031

5864 S. R. Yeh, S. W. Han and D. L. Rousseau (1998) Accounts Chem Res 31:727-736

5965 A. Macone, S. Masciarelli, F. Palombarini, D. Quaglio, A. Boffi, M. C. Trabuco, P. Baiocco, F. Fazi and A. Bonamore (2019) Scientific reports 9(1): art. No. 11749

666 S. Santra, C. Kaittanis and J. M. Perez (2010) Mol Pharmaceut 7:1209-1222 
6167 M. Morales-Cruz, C. M. Figueroa, T. Gonzalez-Robles, Y. Delgado, A. Molina, J. Mendez, M. Morales and K. Griebenow (2014) J Nanobiotechnol 12: Art. No. 33

6268 M. Saxena, Y. Delgado, R. K. Sharma, S. Sharma, S. L. P. D. Guzman, A. D. Tinoco and K. Griebenow (2018) Plos One 13(4): Art. No. e0195542.

6369 S. K. Kim, M. B. Foote and L. Huang (2012) Biomaterials 33:3959-3966

6470 J. Mendez, M. M. Cruz, Y. Delgado, C. M. Figueroa, E. A. Orellano, M. Morales, A. Monteagudo and K. Griebenow (2014) Mol Pharmaceut 11:102-111

\section{Tables and Figures}

Table 1. The main adducts of C1, C2, C3 and C4 with Ly and Cyt identified by deconvoluted ESI MS spectra after incubation of complexes with proteins in $20 \mathrm{mM}$ ammonium hydrogen carbonate $\mathrm{pH} 7.4$ at $37{ }^{\circ} \mathrm{C}$ for $24 \mathrm{~h}$ and $48 \mathrm{~h}$. The relative peak intensity of adducts is in comparison to nonderivatized Ly/Cyt in each individual mass spectrum, which is 100.

\begin{tabular}{|c|c|c|c|c|c|}
\hline \multirow{2}{*}{ Sample } & Exp. mass & Exp. mass & Modification & Theor. mass & Delta \\
\hline & of adduct & increase & & of adduct & mass \\
\hline
\end{tabular}

\begin{tabular}{|c|c|c|c|c|c|c|}
\hline \multicolumn{7}{|c|}{ C1 } \\
\hline Ly $24 \mathrm{~h}$ & 14711.9631 & 406.9911 & [RuCymL] & 14713.0241 & -1.0610 & 1.76 \\
\hline Ly $48 \mathrm{~h}$ & 14711.9402 & 406.0023 & [RuCymL] & 14713.9900 & -2.0498 & 1.12 \\
\hline Cyt $24 \mathrm{~h}$ & 12766.4166 & 406.9972 & [RuCymL] & 12767.4715 & -1.0549 & 1.25 \\
\hline Cyt $48 \mathrm{~h}$ & 12766.4077 & 406.9986 & [RuCymL] & 12767.4612 & -1.0535 & 1.61 \\
\hline \multicolumn{7}{|c|}{$\mathrm{C2}$} \\
\hline \multirow{3}{*}{ Ly $24 \mathrm{~h}$} & 14539.8905 & 233.9681 & {$[\mathrm{RuCym}]^{2+}$} & 14541.9352 & -2.0447 & 0.78 \\
\hline & 14600.8940 & 294.9716 & {$\left[\mathrm{RuCym}\left(\mathrm{CO}_{3}\right)\right]$} & 14601.9110 & -1.0259 & 1.13 \\
\hline & 14700.9435 & 395.0211 & {$\left[\mathrm{RuCym}\left(\mathrm{CO}_{3}\right)\right], \mathrm{Ru}^{2+}$} & 14703.8243 & -2.8808 & 1.41 \\
\hline \multirow{2}{*}{ Ly $48 \mathrm{~h}$} & 14538.8742 & 232.9384 & {$[\mathrm{RuCym}]^{2+}$} & 14541.9486 & -3.0744 & 0.73 \\
\hline & 14599.8843 & 293.9485 & {$\left[\mathrm{RuCym}\left(\mathrm{CO}_{3}\right)\right]$} & 14601.9334 & -2.0490 & 1.03 \\
\hline
\end{tabular}




\begin{tabular}{|c|c|c|c|c|c|c|}
\hline & 14700.9457 & 395.0099 & {$\left[\operatorname{RuCym}\left(\mathrm{CO}_{3}\right)\right], \mathrm{Ru}^{2+}$} & 14703.8377 & -2.8920 & 1.65 \\
\hline Cyt $24 \mathrm{~h}$ & 12593.3846 & 233.9911 & {$[\mathrm{RuCym}]^{2+}$} & 12595.4063 & -2.0217 & 11.09 \\
\hline Cyt $48 \mathrm{~h}$ & 12593.4239 & 233.9813 & {$[\mathrm{RuCym}]^{2+}$} & 12595.4554 & -2.0315 & 10.93 \\
\hline \multicolumn{7}{|c|}{$\mathbf{C 3}$} \\
\hline \multirow{3}{*}{ Ly $24 \mathrm{~h}$} & 14538.8795 & 233.9243 & {$[\mathrm{RuCym}]^{2+}$} & 14540.9680 & -2.0885 & 0.96 \\
\hline & 14600.8935 & 295.9383 & {$\left[\operatorname{RuCym}\left(\mathrm{CO}_{3}\right)\right]$} & 14600.9528 & -0.0592 & 1.51 \\
\hline & 14701.9495 & 396.9943 & {$\left[\mathrm{RuCym}\left(\mathrm{CO}_{3}\right)\right], \mathrm{Ru}^{2+}$} & 14702.8571 & -0.9076 & 1.57 \\
\hline \multirow{3}{*}{ Ly $48 \mathrm{~h}$} & 14537.8845 & 231.9414 & {$[\mathrm{RuCym}]^{2+}$} & 14541.9559 & -4.0714 & 0.81 \\
\hline & 14600.8907 & 294.9476 & {$\left[\mathrm{RuCym}\left(\mathrm{CO}_{3}\right)\right]$} & 14601.9407 & -1.0499 & 1.22 \\
\hline & 14700.9495 & 395.0064 & {$\left[\operatorname{RuCym}\left(\mathrm{CO}_{3}\right)\right], \mathrm{Ru}^{2+}$} & 14703.8450 & -2.8955 & 1.82 \\
\hline Cyt $24 \mathrm{~h}$ & 12593.3969 & 233.9919 & {$[\mathrm{RuCym}]^{2+}$} & 12595.4178 & -2.0209 & 12.3 \\
\hline Cyt $48 \mathrm{~h}$ & 12594.4366 & 234.9794 & {$[\mathrm{RuCym}]^{2+}$} & 12595.4699 & -1.0333 & 8.67 \\
\hline \multicolumn{7}{|c|}{$\mathrm{C4}$} \\
\hline \multirow{6}{*}{ Ly $24 \mathrm{~h}$} & 14538.8650 & 233.8980 & [RuCym]2+ & 14540.9798 & -2.1148 & 0.19 \\
\hline & 14599.8866 & 294.9196 & {$\left[\mathrm{RuCym}\left(\mathrm{CO}_{3}\right)\right]$} & 14600.9646 & -1.0779 & 0.14 \\
\hline & 14699.9566 & 394.9896 & {$\left[\mathrm{RuCym}\left(\mathrm{CO}_{3}\right)\right], \mathrm{Ru}^{2+}$} & 14702.8689 & -2.9123 & 0.11 \\
\hline & 14775.9108 & 470.9438 & [RuCymL] & 14777.9926 & -2.0818 & 0.07 \\
\hline & 14857.9089 & 552.9419 & {$\left[\mathrm{RuCym}\left(\mathrm{CO}_{3}\right)\right]$} & 14853.9801 & 3.9288 & 0.07 \\
\hline & & & {$[\operatorname{RuCym}(\mathrm{OH})]^{1+}$} & & & \\
\hline \multirow{3}{*}{ Ly $48 \mathrm{~h}$} & 14538.9392 & 233.9668 & {$[\mathrm{RuCym}]^{2+}$} & 14540.9852 & -2.0460 & 0.82 \\
\hline & 14598.9395 & 293.9671 & {$\left[\mathrm{RuCym}\left(\mathrm{CO}_{3}\right)\right]$} & 14600.9610 & -2.0304 & 0.66 \\
\hline & 14701.0202 & 396.0478 & {$\left[\mathrm{RuCym}\left(\mathrm{CO}_{3}\right)\right], \mathrm{Ru}^{2+}$} & 14702.8743 & -1.8541 & 1.68 \\
\hline \multirow{2}{*}{ Cyt 24 h } & 12593.3657 & 233.9538 & {$[\mathrm{RuCym}]^{2+}$} & 12595.4247 & -2.0590 & 1.01 \\
\hline & 12830.3888 & 470.9769 & [RuCymL] & 12832.4375 & -2.0487 & 0.61 \\
\hline Cyt $48 \mathrm{~h}$ & 12594.3601 & 233.9651 & {$[\mathrm{RuCym}]^{2+}$} & 12596.4078 & -2.0477 & 0.99 \\
\hline
\end{tabular}




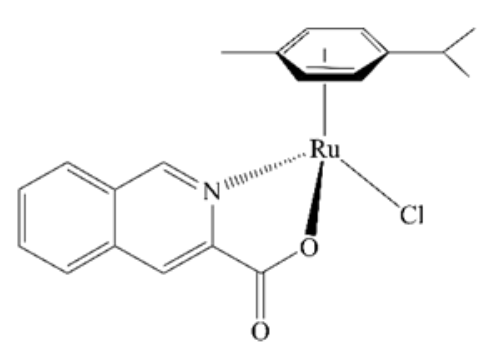

C1
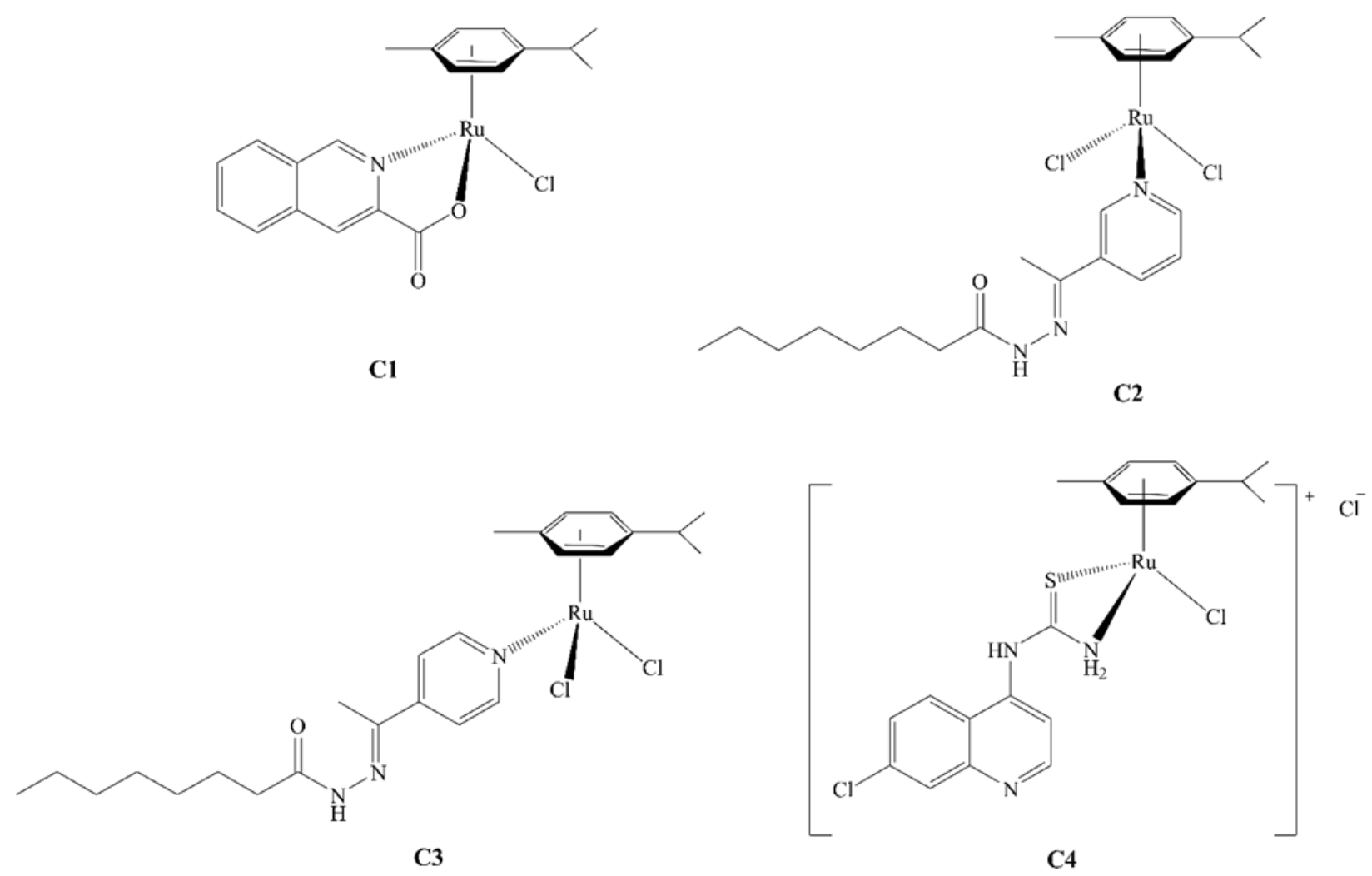

Figure 1. Structures of investigated complexes: (C1) [( $\eta^{6}-p$-cymene $\left.) \mathrm{RuL} 1 \mathrm{Cl}\right],(\mathrm{C} 2)\left[\left(\eta^{6}-p\right.\right.$ cymene $\left.\mathrm{RuL} 2 \mathrm{Cl}_{2}\right],(\mathrm{C} 3)\left[\left(\eta^{6}-p\right.\right.$-cymene $\left.) \mathrm{RuL} 3 \mathrm{Cl}_{2}\right],(\mathrm{C} 4)\left[\left(\eta^{6}-p\right.\right.$-cymene $\left.) \mathrm{RuL} 4 \mathrm{Cl}\right] \mathrm{Cl}$ 

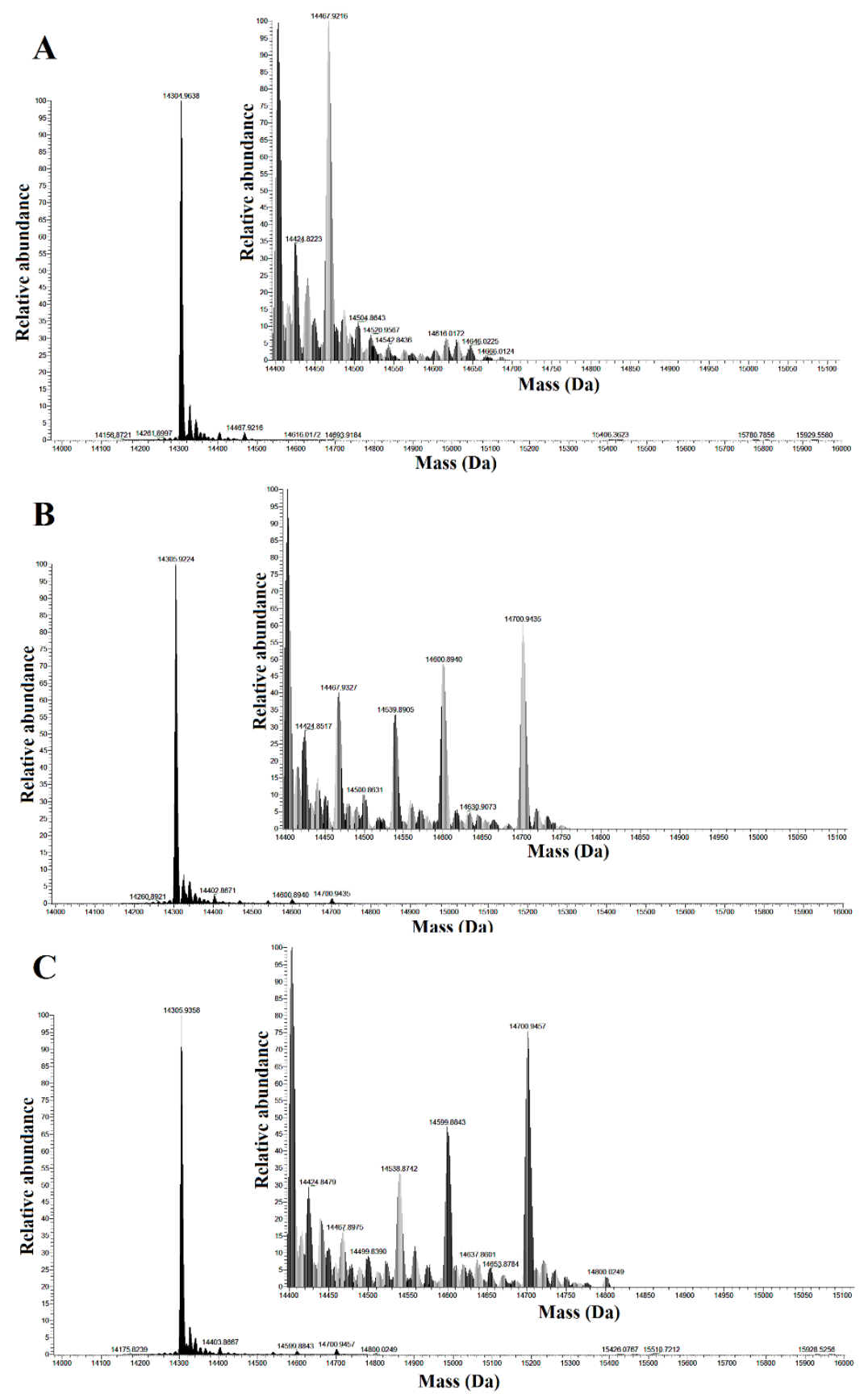

Figure 2. (A) Deconvoluted ESI-MS spectra of Ly incubated for $24 \mathrm{~h}$. Deconvoluted ESI-MS spectra of Ly incubated with C2 during $24 \mathrm{~h}(\mathrm{~B})$ and $48 \mathrm{~h}(\mathrm{C})$. The samples were incubated in 20 $\mathrm{mM}$ ammonium hydrogen carbonate $\mathrm{pH} 7.4$ at $37^{\circ} \mathrm{C}$. Inserts represent corresponding zoom out of mass region 14400-15400 Da 

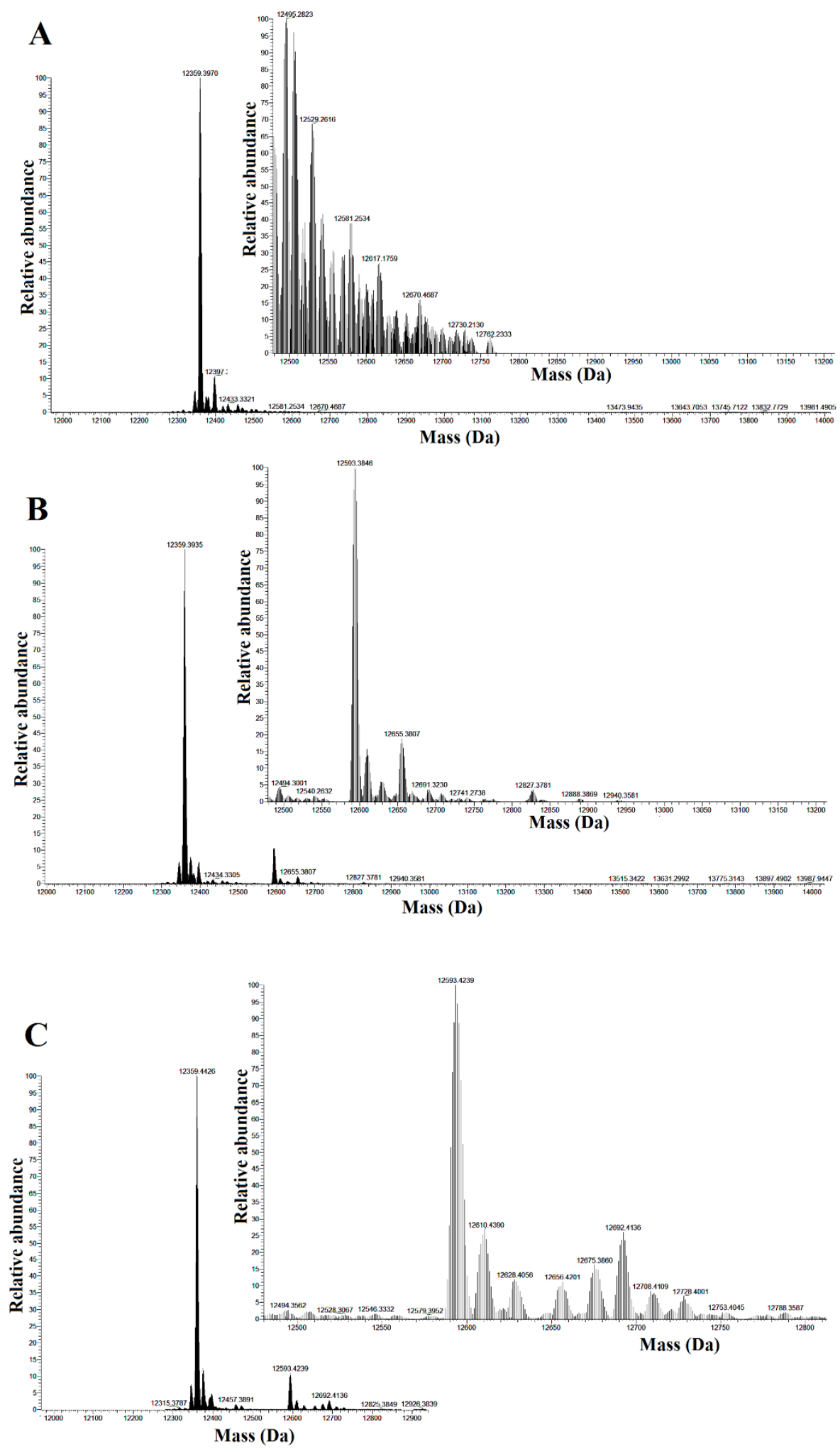
Figure 3. (A) Deconvoluted ESI-MS spectra of Cyt incubated for $24 \mathrm{~h}$. Deconvoluted ESI-MS spectra of Cyt incubated with C2 during $24 \mathrm{~h}(\mathrm{~B})$ and $48 \mathrm{~h}(\mathrm{C})$. The samples were incubated in $20 \mathrm{mM}$ ammonium hydrogen carbonate $\mathrm{pH} 7.4$ at $37^{\circ} \mathrm{C}$. Inserts represent corresponding zoom out of mass region 12500-13500 Da
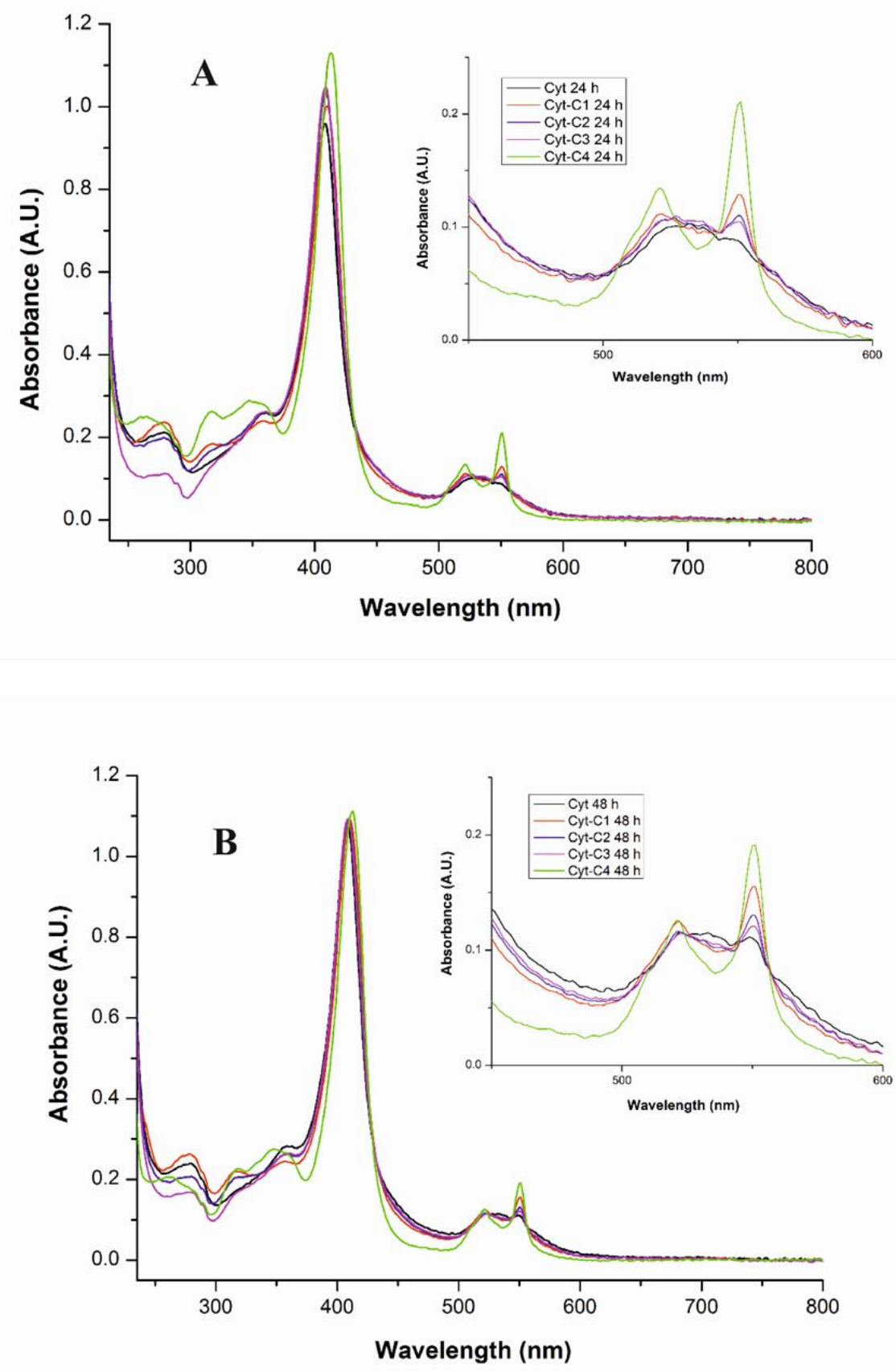
Figure 4. Absorption UV-vis spectra of cytrochrome c in $20 \mathrm{mM}$ ammonium hydrogen carbonate pH 7.4 before and after addition of $\mathbf{C 1}, \mathbf{C 2}, \mathbf{C 3}$ and $\mathbf{C 4}$. Spectra were recorded at 37 ${ }^{\circ} \mathrm{C}$ after $24 \mathrm{~h}(\mathrm{~A})$ and after $48 \mathrm{~h}$ (B). Insets show the spectra more in detail (region 450-600 nm).
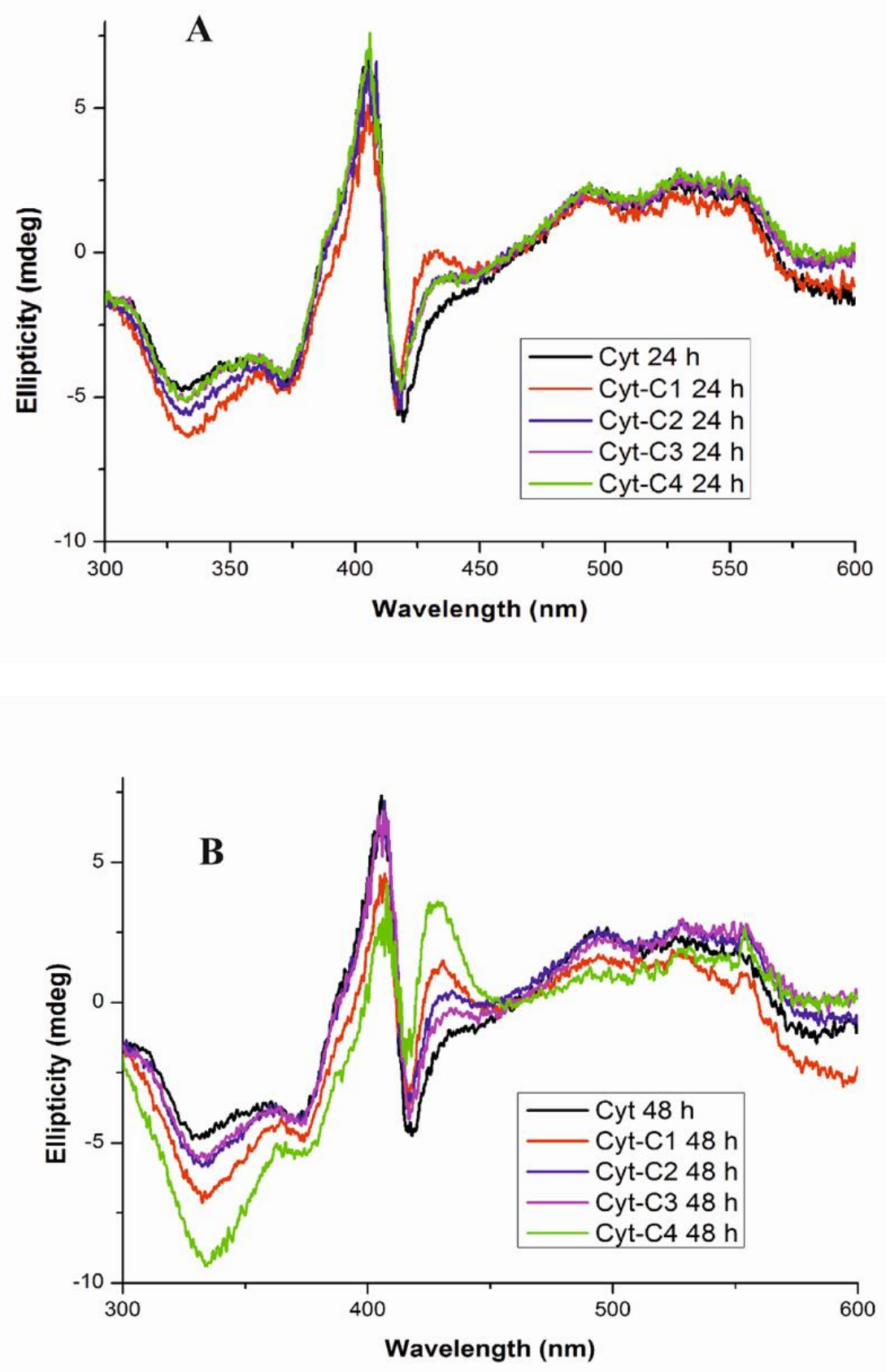
Figure 5. The effect of $\mathrm{Ru}(\mathrm{II})$ complexes on the Soret $\mathrm{CD}$ intensity of Cyt. Cyt and Cyt incubated with C1, C2, C3 and C4 were incubated in $20 \mathrm{mM}$ ammonium hydrogen carbonate $\mathrm{pH}$ 7.4 for $24 \mathrm{~h}(\mathrm{~A})$ and $48 \mathrm{~h}(\mathrm{~B})$ at $37^{\circ} \mathrm{C}$ at the molar ratio $\mathrm{Ru}(\mathrm{II}) / \mathrm{Cyt}=3: 1, \mathrm{Cyt}=100 \mathrm{uM}$. 